\title{
STABILNOST SAĆASTIH NOSAČA IZLOŽENIH SAVIJANJU
}

\author{
Ivan Radić
}

Sveučilište J. J. Strossmayera u Osijeku, Građevinski fakultet Osijek, dipl.ing.građ.

Mario Deljak

Sveučilište J. J. Strossmayera u Osijeku, Građevinski fakultet Osijek, student

\section{Damir Markulak}

Sveučilište J. J. Strossmayera u Osijeku, Građevinski fakultet Osijek, prof.dr.sc.

Sažetak: Relativno velike vitkosti i značajna prošupljenja hrpta čine saćaste nosače osjetljivim na bočno-torzijsko izvijanje. Prema prednormi [1], pri dokazu otpornosti saćastih nosača na bočno-torzijsko izvijanje, treba u proračunu uzeti geometrijske karakteristike poprečnog presjeka na mjestu otvora, tj. pri izračunu otpornosti na bočno-torzijsko izvijanje promatrati neto poprečni presjek u sredini otvora gdje su geometrijske karakteristike presjeka najmanje. To zapravo znači da se i za saćaste nosače primjenjuje konvencionalni dokaz otpornosti na bočno-torzijsko izvijanje kao i za standardne punostijene nosače, ali uz redukciju geometrijskih karakteristika poprečnog presjeka nosača. Cilj ovog rada je ilustrirati načine proračuna kritičnog momenta bočnog-torzijskog izvijanja saćastih nosača, korištenjem MKE i izraza danih u [1], kako bi se odredio utjecaj prošupljenja hrpta saćastih nosača u odnosu na punostijene nosače istih dimenzija poprečnog presjeka.

Ključne riječi: saćasti nosači, punostijeni nosači, bočno-torzijsko izvijanje, 3D MKE modeli

\section{STABILITY OF CASTELLATED BEAMS EXPOSED TO BENDING}

\begin{abstract}
Because of the relatively high slenderness of castellated beams and significant area of the openings in the web, one of the possible failure modes is the lateral-torsional buckling. The simplified verification of the resistance for the lateral-torsional buckling is proposed in [1], which implies the similar calculation for the lateraltorsional buckling as for the standard plate beams but with the reduction of geometrical characteristics of crosssection. This calculation method uses geometrical characteristics of a cross-section through openings. It implies that the validation of lateral buckling resistance is the same for a castellated beam and standard plate girder but with the reduction of the castellated beam cross-section geometrical characteristics. The aim of this research is to show procedures for the calculation of the critical moment for the castellated beams, using FEM and expression given in [1], in order to determine the influence of the reduced geometrical characteristics of the castellated beams in relation to the plated beams with the same cross-section dimensions.
\end{abstract}

Key words: castellated beams, plated beams, lateral-torsional buckling, 3D FEM models 


\section{Uvod}

Saćasti nosači su racionalno konstrukcijsko rješenje u slučaju potrebe premošćivanja većih raspona nosačima dominantno optrećenih savijanjem oko svoje jače osi. Ovi nosači izrađuju se rezanjem I nosača po hrptu, nakon čega se jedna polovica nosača pomiče i zavaruje s drugom polovicom. Ovakvo povećavanje visine presjeka nosača rezultira povećanjem momenta tromosti prejeka, a samim time i njegovom povećanom otpornošću na savijanje. Prednost saćastih nosača je i što otvori u hrptu mogu poslužiti za provođenje instalacija pri čemu nema potrebe za dodatnim povećanjem visine konstrukcije. Saćaste nosače moguće je izvesti i s promjenjivim poprečnim presjekom, a različitim načinima rezanja hrpta moguće je dobiti i različite oblike otvora (slika 1).
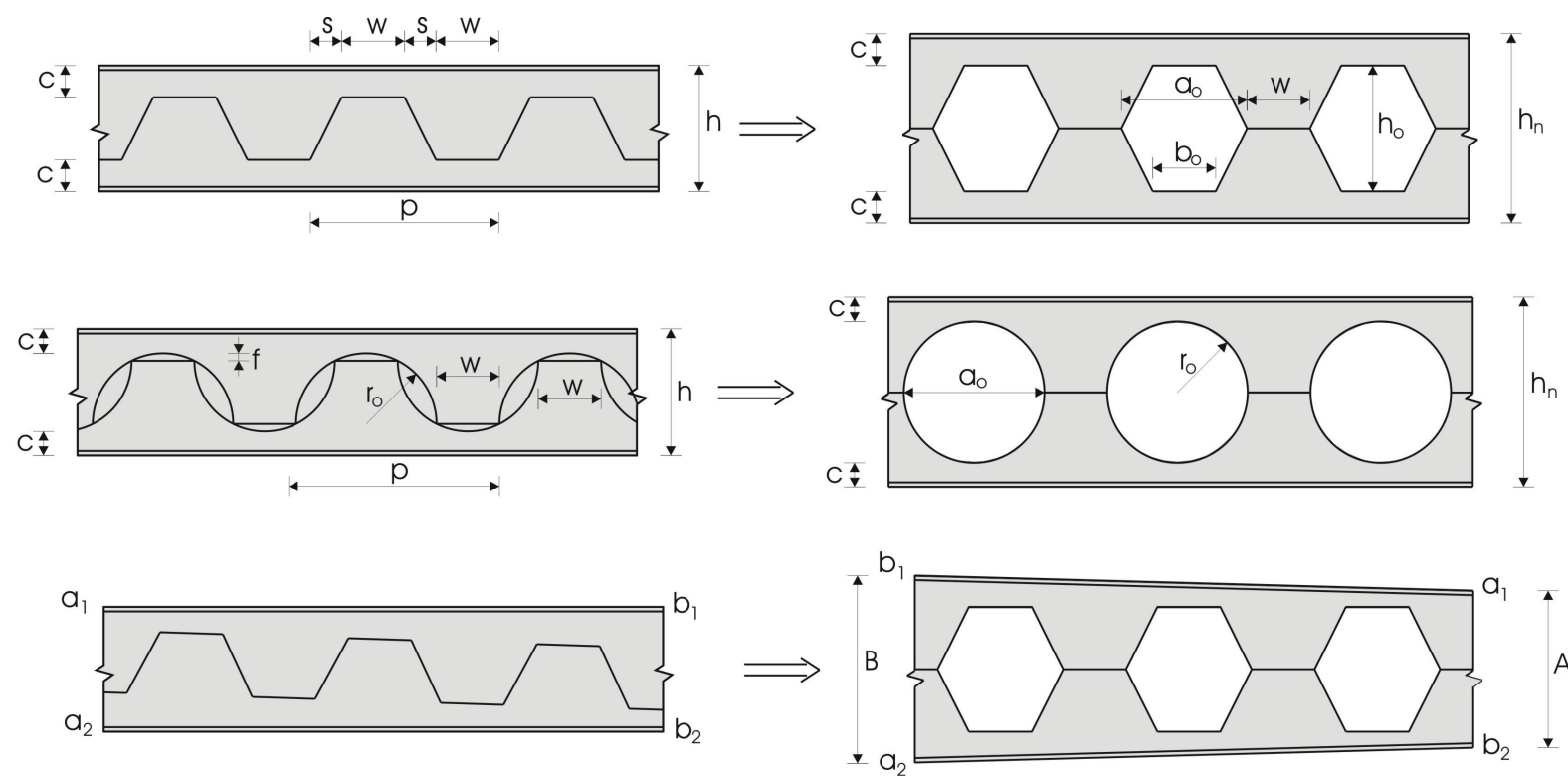

\section{Slika 1 - Saćasti nosači}

Nedostatci saćastih nosača očituju se manjom požarnom otpornošću u odnosu na punostijene nosače, te potrebom za poprečnim ukrućenjima hrpta ako na nosač djeluju koncentrirane sile većih intenziteta.

Otvori u hrptu mogu biti kružni i poligonalni, pravilni i nepravilni (slika 2.), a Eurokod 3 [1] daje geometrijske preporuke za njihove dimenzije i položaj:

$$
\begin{aligned}
& h_{0} \leq 0,75 \cdot d_{w}-\text { za poligonalne otvore } \\
& h_{0} \leq 0,80 \cdot d_{w}-\text { za kružne otvore } \\
& d_{1}=d_{2} \geq 0,10 \cdot d_{w} \\
& a_{0} \leq h_{0} \\
& b_{0}=w \\
& 0,25 \cdot a_{0} \leq w \leq 0,50 \cdot a_{0}
\end{aligned}
$$
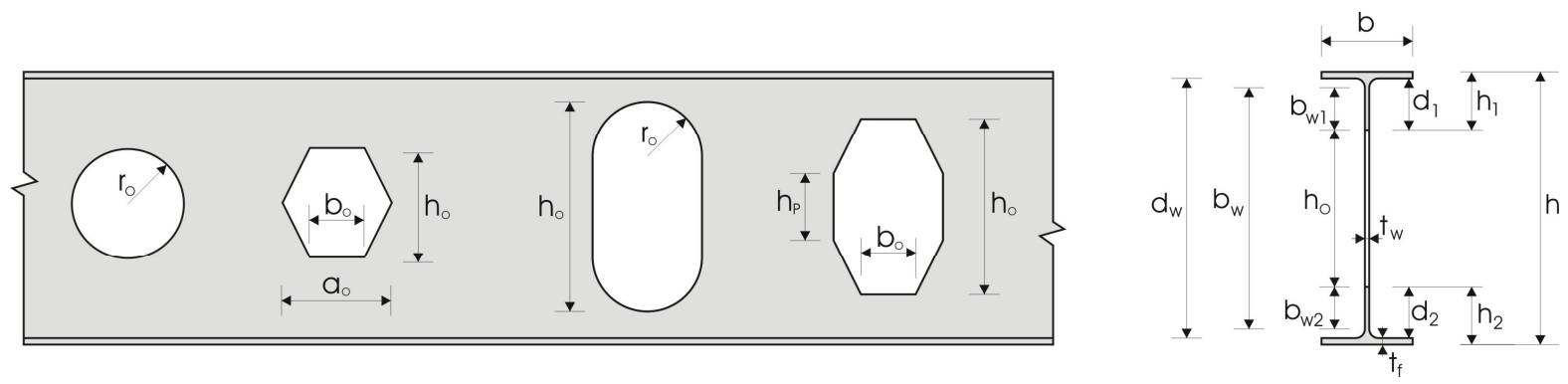

Slika 2 - Različiti oblici otvora u hrptu 
Otpornost saćastih nosača treba kontrolirati na:

- poprečnu silu na oslabljenom poprečnom presjeku (na mjestu otvora);

- uzdužnu silu kao posljedicu djelovanja momenta savijanja;

- moment savijanja na Vierendeel-ovom nosaču kao posljedicu djelovanja poprečnih sila;

- mogućnost tečenja ili bočnog izvijanja zbog djelovanja momenta u dijelu hrpta između otvora;

- poprečnu silu u dijelu hrpta između otvora ili na mjestima zavara.

U ovom se radu istražuje mogućnost gubitka stabilnosti saćastih nosača bočnim izvijanjem, budući da se radi o relativno vitkim nosačima koji su dodatno oslabljeni otvorima u hrptu.

\section{Općenito o bočnom-torzijskom izvijanju}

Bočno-torzijsko izvijanje je problem gubitka stabilnosti nosača te otkazivanja nosivosti prije pojave plastifikacije nosača. Na pojavu bočnog-torzijskog izvijanja osjetjivi su nosači primarno konstruirani za preuzimanje sila u svojoj jačoj ravnini, dok im je krutost na savijanje oko slabije osi manja (I i U presjeci). Elastični kritični moment bočnog-torzijskog izvijanja $M_{c r}$, koji prema teoriji elastičnosti predstavlja najmanji moment pri kojemu dolazi do pojave bočnog-torzijskog izvijanja, prema [2] za dvoosno simetrične presjeke računa se iz izraza:

$$
M_{c r}=C_{1} \frac{\pi^{2} \cdot E \cdot I_{z}}{(k \cdot L)^{2}} \cdot\left[\sqrt{\left(\frac{k}{k_{w}}\right)^{2} \cdot \frac{I_{w}}{I_{z}}+\frac{(k \cdot L)^{2} \cdot G \cdot I_{t}}{\pi^{2} \cdot E \cdot I_{z}}+\left(C_{2} \cdot z_{g}\right)^{2}}-C_{2} \cdot z_{g}\right]
$$

gdje su:

$C_{1}, C_{2}$ - faktori ovisni o uvjetu opterećenja

$k$ - faktor efektivne dužine bočnog-torzijskog izvijanja izvan ravnine opterećenja

$k_{w}$ - faktor efektivne dužine bočnog-torzijskog izvijanja koji uzima u obzir krivljenje krajeva nosača

$I_{z}$ - moment inercije oko osi z-z

$I_{w}$ - konstanta krivljenja

$I_{t}$ - torzijska konstanta

$G$ - modul posmika

$Z_{g}$ - udaljenost između točke u kojoj djeluje opterećenje i centra posmika.

Izraz (4) vrlo je osjetljiv na faktore $k$ i $k_{w}$ čija je geometrijska interpretacija prikazana na slici 3.

Otpornost nosača na bočno-torzijsko izvijanje $M_{b, R d}$, koja mora biti veća od računskog momenta $M_{y, E d}$ koji djeluje na nosač, dobije se tako da se otpornost poprečnog presjeka na savijanje smanji faktorom redukcije $\chi_{L T}$ [2]:

$$
M_{b, R d}=\chi_{L T} \cdot \frac{\beta_{w} \cdot W_{p l, y} \cdot f_{y}}{\gamma_{M 1}}
$$

Faktor redukcije za bočno-torzijsko izvijanje $\chi_{L T}$ određuje se prema izrazu:

$$
\chi_{L T}=\frac{1}{\Phi_{L T}+\sqrt{\Phi_{L T}^{2}-\bar{\lambda}_{L T}^{2}}} \text {, ali } \chi_{L T} \leq 1,0
$$

gdje je:

$$
\begin{aligned}
& \bar{\lambda}_{L T}=\sqrt{\frac{\beta_{w} \cdot W_{p l, y} \cdot f_{y}}{M_{c r}}} \\
& \beta_{w}=\frac{W_{y}}{W_{p l, y}} \\
& \Phi_{L T}=0,5\left[1+\alpha_{L T}\left(\bar{\lambda}_{L T}-0,2\right)+\bar{\lambda}_{L T}^{2}\right]
\end{aligned}
$$


$\alpha_{\text {LT }}$ - faktor imperfekcije, čija vrijednost ovisi o liniji izvijanja koja se bira ovisno o vrsti i geometrijskim karakteristikama promatranog nosača

Saćasti se nosači zbog svoje relativno velike vitkosti, primjene kod većih raspona te značajne prošupljenosti hrpta (i do $75 \%$ u odnosu na puni hrbat) mogu također svrstati u nosače vrlo osjetljive na bočno-torzijsko izvijanje. Prema [1], pri dokazu otpornosti saćastih nosača na bočno-torzijsko izvijanje, treba u proračunu uzeti geometrijske karakteristike poprečnog presjeka na mjestu otvora, tj. pri izračunu otpornosti na bočno-torzijsko izvijanje promatrati neto poprečni presjek u sredini otvora, gdje su geometrijske karakteristike presjeka najmanje. To zapravo znači da se i za saćaste nosače primjenjuje konvencionalni dokaz otpornosti na bočno-torzijsko izvijanje kao i za standardne punostijene nosače, ali uz redukciju geometrijskih karakteristika poprečnog presjeka nosača.

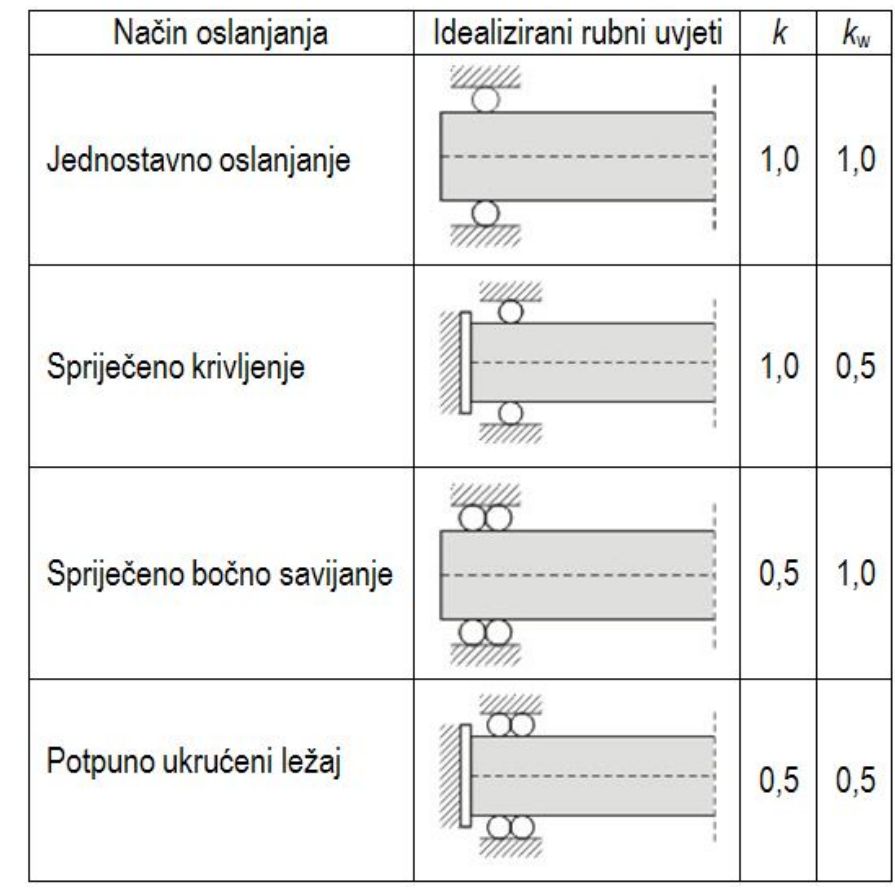

\section{Slika 3 - Interpretacija faktora $k \mathrm{i} \boldsymbol{k}_{\mathrm{w}}$}

Za cilj istraživanja u ovome radu se stoga postavlja ocjena točnosti ovakvog pojednostavljenog pristupa dokazu otpornosti saćastih nosača na bočno-torzijsko izvijanje, budući da se ipak radi o problemu stabilnosti nosača koji u promatranom slučaju nema jednoliki poprečni presjek duž čitavog raspona.

\section{Metode proračuna}

Iz postavljenog cilja rada proizlazi da je zapravo potrebno utvrditi koliko otvori u hrptu kod saćastih nosača imaju utjecaja na smanjenje nosivosti na bočno-torzijsko izvijanje u odnosu na pločaste punostijene nosače istih gabarita (iste visine, širine i debljine pojasnica, debljine hrpta). U tom smislu su provedeni proračuni elastičnog kritičnog momenta bočnog-torzijskog izvijanja prema [2], $\left(M_{c r}^{E C}\right)$, te primjenom metode konačnih elemenata korištenjem linearne analize izvijanja (eng. linear buckling analysis), $\left(M_{c r}^{M K E}\right)$.

Općenito, linearna analiza izvijanja polazi od jednadžbe ravnoteže za konstrukciju opterećenu konstantnom silom:

$$
[K]\{u\}=\{P\}
$$


gdje je:

$[K]$ - matrica krutosti

$\{u\}$ - vektor pomaka

$\{P\}$ - vektor vanjskog opterećenja

Da bi se u obzir uzele diferencijalne promjene krutosti, uvodi se matrica diferencijalnih krutosti [K $\left.K_{D}\right]$ (uključivanjem izraza višeg reda iz odnosa naprezanje-deformacija a uz pretpostavku da su ti odnosi neovisni 0 vrijednosti opterećenja). Različite «intenzitete» opterećenja moguće je simulirati uvođenjem skalarnog množitelja $\mathrm{k}_{\mathrm{cr}}$, te jednadžba ravnoteže (9) prelazi u:

$$
\left([K]+k_{c r}\left[K_{D}\right]\right)\left\{u^{*}\right\}=\left\{k_{c r} P\right\}
$$

gdje je $\left\{u^{*}\right\}$ modificirani vektor pomaka koji je rezultat pomaka od opterećenja i diferencijalnih promjena krutosti. Pobuđivanjem razmatranog konstrukcijskog elementa postepeno, raznim intenzitetima opterećenja (uz pomoć faktora $k_{c r}$, može doći do nestabilnosti uvjeta ravnoteže, tj. opterećenje pomnoženo s faktorom $k_{c r}$ uzrokovat će izvijanje:

$$
\left([K]+k_{c r}\left[K_{D}\right]\right)\left\{u^{*}\right\}=0
$$

Jednadžba (11) svodi se na problem vlastitih vrijednosti:

$$
\left[K-k_{c r} K_{D}\right]\{\varphi\}=0
$$

Rješenje je netrivijalno ( $k_{c r}$ različit od 0 ) samo za specifične vrijednosti faktora $k_{c r}$ koji matricu $\left[K-k_{c r} K_{D}\right]$ čine singularnom. Umnožak prve vlastite vrijednosti faktora $k_{c r} s$ opterećenjem dat će prvo kritično opterećenje izvijanja modela, odnosno prvi oblik izvijanja (vlastiti vektor $\varphi$ ), koji je za praktične slučajeve najvažniji.

Opisani postupak primjene linearne elastične analize izvijanja za proračun kritičnog faktora «intenziteta» opterećenja, $k_{c r}$, u ovom je radu proveden uz pomoć programskog paketa Robot Millennium, [3]. Dakle, rezultat proračuna modela u Linear buckling analysis modulu programa Robot Millenium su kritični koeficijenti intenziteta opterećenja $k_{c r}$ za svaki oblik (mod) izvijanja.

Množenjem tako izračunatog faktora intenziteta opterećenja s opterećenjem kojemu je model nosača u analizi izložen, dobije se kritično opterećenje pri kojemu dolazi do gubitka stabilnosti nosača, odnosno njegovog izvijanja. Kada je poznat kritični iznos opterećenja više nije teško izračunati kritičnu vrijednost momenta savijanja pri kojem dolazi do izvijanja, a što ovisi o statičkom sustavu razmatranog konstrukcijskog elementa, te vrsti i raspodjeli opterećenja.

U ovom su radu razmatrani slobodno oslonjeni nosači različith raspona, opterećeni jednoliko raspodijeljenim opterećenjem i koncentriranom silom u sredini raspona, te su kritični momenti savijanja za pojavu bočnog-torzijskog izvijanja određivani prema izrazima:

$$
M_{c r}^{M K E}=k_{c r} \frac{q \cdot L^{2}}{8} \text { i } M_{c r}^{M K E}=k_{c r} \frac{P \cdot L}{4}
$$

gdje je:

$$
\begin{aligned}
& k_{c r}-\text { kritični faktor } \\
& q-\text { jednoliko opterećenje } \\
& L \text { - raspon saćastog nosača. }
\end{aligned}
$$

Za proračune su izabrane dvije skupine valjanih profila - IPE i HE-A, s obzirom na različite geometrijske karakteristike presjeka, [4]. Pretpostavljeno je da se saćasti nosači koriste kao krovne grede. Analize su provedene na saćastim nosačima čija je visina $50 \%$ veća u odnosu na izvorne IPE i HE-A profile. Rasponi i odabrani poprečni presjeci razmatranih nosača prikazani su u tablici 1.

Opterećenja za sve nosače su se nalazila na gornjoj (tlačnoj) pojasnici. Svaki od dva modela nosača analiziran je za dva različita slučaja bočnog-torzijskog oslanjanja, tj. za slučajeve:

$-k=1,0$ i $k_{w}=1,0$,

$-k=1,0 i k_{w}=0,5$. 


\section{Tablica 1 - Geometrijske karakteristike analiziranih saćastih nosača}

\begin{tabular}{|l|c|c|c|c|c|}
\hline $\begin{array}{c}\text { POPREČNI } \\
\text { PRESJEK }\end{array}$ & $\begin{array}{c}\text { Visina } \\
\text { izvornog } \\
\text { profila } \\
{[\mathrm{mm}]}\end{array}$ & $\begin{array}{c}\text { Visina } \\
\text { saćastog } \\
\text { nosača } \\
{[\mathrm{mm}]}\end{array}$ & $\begin{array}{c}\text { Raspon } \\
\text { grede } \\
{[\mathrm{m}]}\end{array}$ & $\begin{array}{c}\text { Širina }\left(a_{0}\right) \\
\text { i visina }\left(h_{0}\right) \\
\text { otvora } \\
{[\mathrm{mm}]}\end{array}$ & $\begin{array}{c}\text { Razmak } \\
\text { otvora }(w) \\
{[\mathrm{mm}]}\end{array}$ \\
\hline IPE 240 & 240 & 360 & 8,0 & 253,5 & 126,75 \\
\hline HE 220A & 210 & 315 & 8,0 & 213,0 & 106,5 \\
\hline
\end{tabular}

U Robot Milleniumu izrađeno je ukupno 4 3D modela uz korištenje konačnih elemenata tipa SHELL. Posebna pozornost posvećena je modeliranju rubnih uvjeta za različite slučajeve bočnog oslanjanja, jer je uočeno da se i pri malim korekcijama rubnih uvjeta dobivaju značajne razlike u rezultatima. Zbog toga su kao "kontrolni modeli“ modelirani i punostijeni nosači istih geometrijskih karakteristika kao razmatrani saćasti, a za koje je bilo moguće primijeniti konvencionalni «ručni» dokaz otpornosti na bočno-torzijsko izvijanje prema [2].

\section{Rezultati proračuna}

U tablici 2. sadržani su rezultati provedenih istraživanja elastičnih kritičnih momenata bočnog-torzijskog izvijanja saćastih nosača: korištenjem izraza (14) - $M_{c r}^{M K E}$, te prema [2] - $M_{c r}^{E C}$ (izraz (4)). Slika 4 prikazuje rubne uvjete modela i oblike izvijanja za analizirane slučajeve bočnog oslanjanja.

Tablica 2 - Geometrijske karakteristike analiziranih saćastih nosača

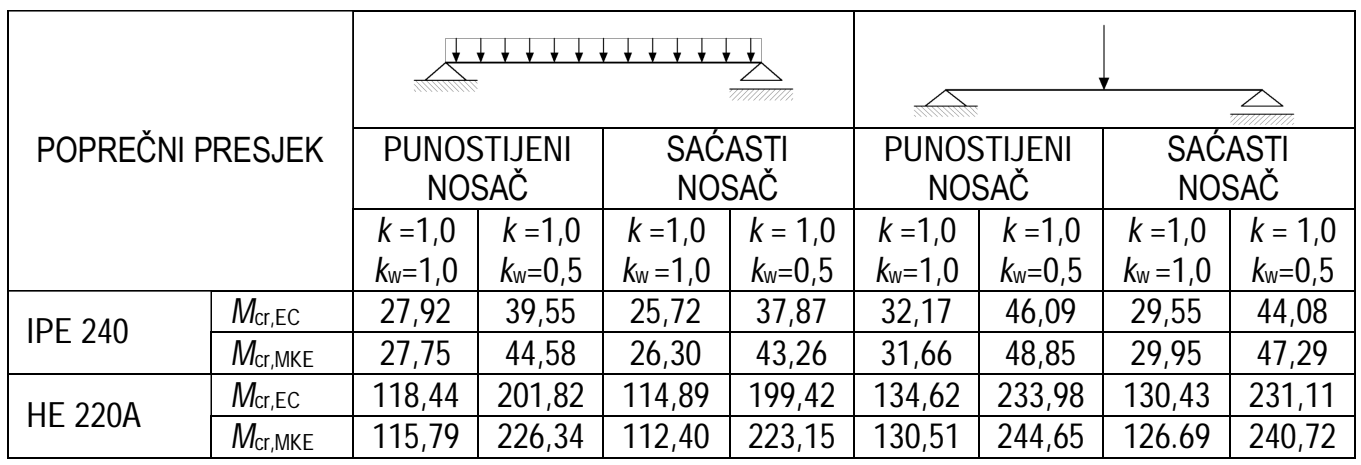
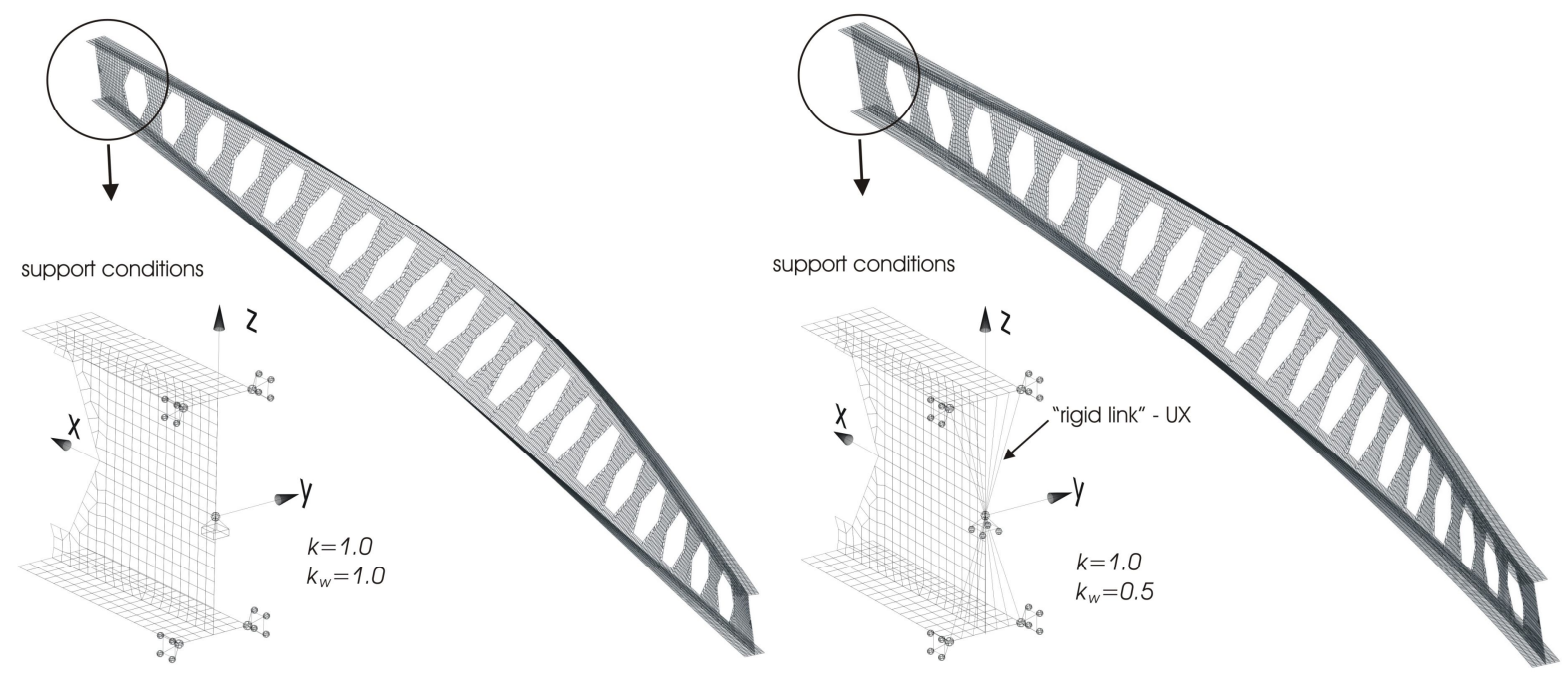

Slika 4 - Rubni uvjeti i oblici izvijanja 
Za tumačenje dobivenih rezultata iz aspekta postavljenog cilja istraživanja potrebno je prvo komentirati dobivene rezultate kritičnih momenata bočnog-torzijskog izvijanja samo za saćaste nosače (određene na ranije opisane načine), te potom i usporediti dobivene vrijednosti kritičnih momenata za saćaste i odgovarajuće punostijene nosače.

Vrijednosti elastičnog kritičnog momenta bočnog-torzijskog izvijanja dobivenih metodom konačnih elemenata su općenito veće od vrijednosti izračunatih korištenjem izraza (13), ali razlike ovise o načinu bočnog oslanjanja i vrsti opterećenja. Praktično iste vrijednosti kritičnog momenta se dobiju za slučaj kada je $k=1,0 \mathrm{i}$ $k_{w}=1,0$. Razlike u vrijednostima su veće za slučaj $k=1,0$ i $k_{w}=0,5$, kao i za slučaj kada su nosači izloženi raspodijeljenom opterećenju (između 10-12\%). Ovo je povezano s koeficijentima $C_{1}$ i $C_{2}$, [2], koji su dani za $k_{w}=1,0$, pri čemu je vrijednost elastičnog kritičnog momenta $M_{\mathrm{cr}, E c}$ konzervativno procijenjena.

Druga usporedba, važnija u okviru ovog rada, odnosi se na vrijednosti kritičnih momenata za saćaste i punostijene nosače različith poprečnih presjeka (IPE i HE-A). Kao što je i očekivano, elastični kritični momenti saćastih nosača, dobiveni korištenjem metode konačnih elemenata, manji su u odnosu na odgovarajuće punostijene nosače, ali su te razlike relativno male (za IPE nosače oko 4\%, a za HE-A nosače oko 2\%). Rezultati „ručnih“ proračuna prate taj trend.

$\mathrm{Na}$ slikama 5 i 6 grafički su ilustrirane odgovarajuće vrijednosti kritičnih momenata za saćaste i odgovarajuće punostijene nosače.

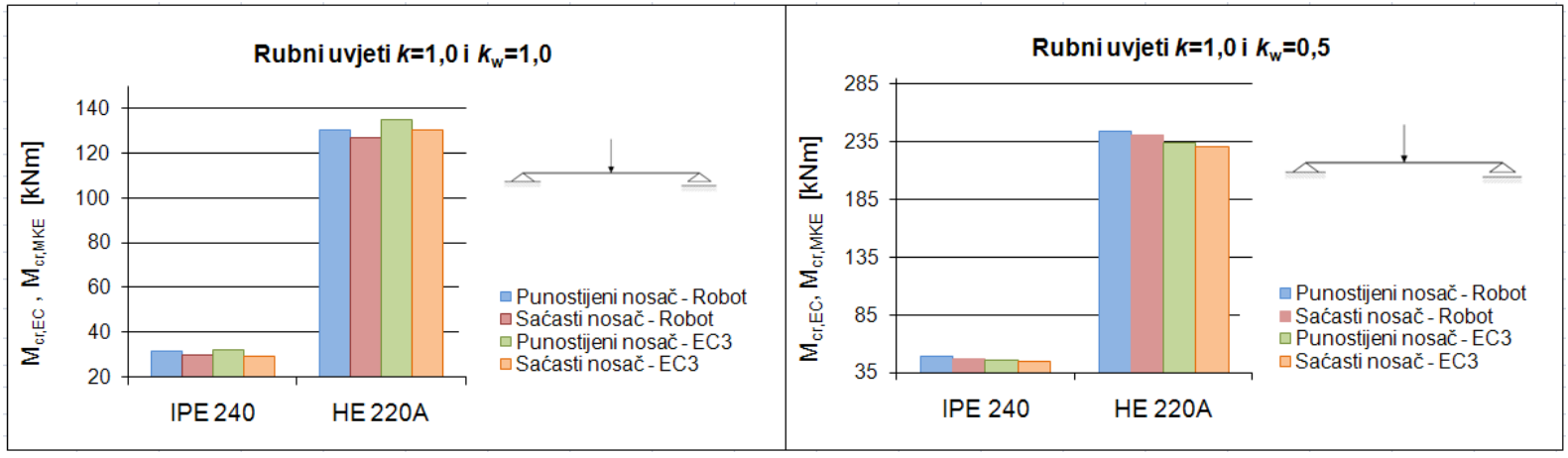

Slika 5 - Elastični kritični moment za slučaj opterećenja koncentriranom silom

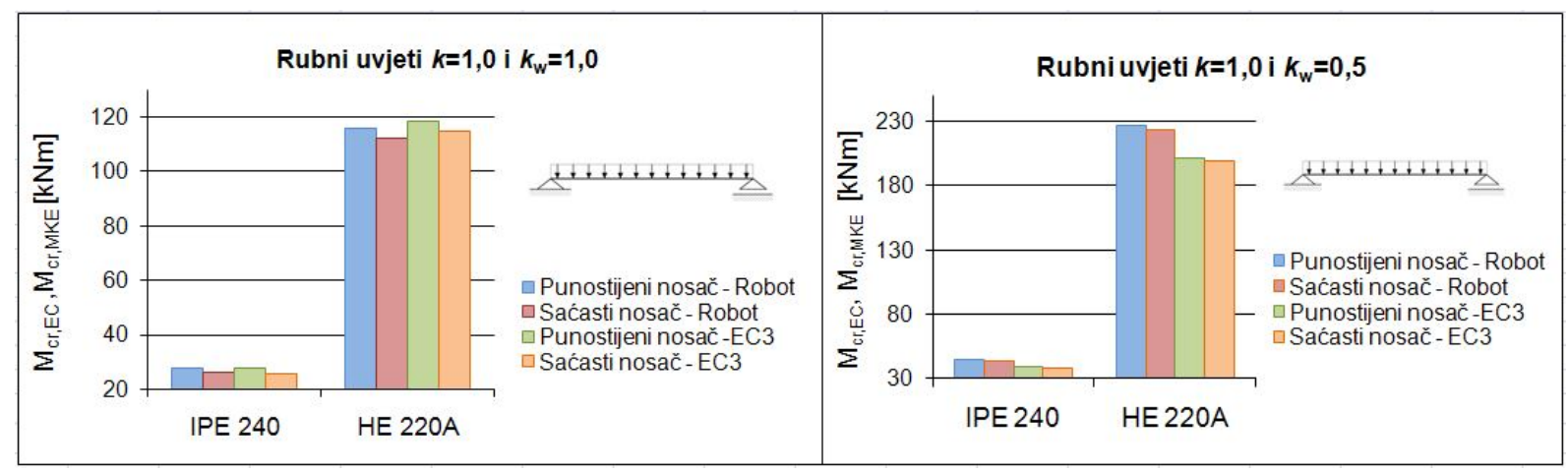

Slika 6 - Elastični kritični moment za slučaj jednoslikog kontinuiranog opterećenja

\section{Zaključak}

U radu su opisani proračuni stabilnosti saćastih nosača iz aspekta otpornosti na bočno-torzijsko izvijanje. Kako bi se izračunala otpornost saćastih nosača na bočno-torzijsko izvijanje prema Eurokodu 3, općenito je prvo potrebno odrediti vrijednost elastičnog kritičnog momenta bočnog-torzijskog izvijanja. 
Ovo sondažno istraživanje imalo je za cilj procijeniti utjecaj geometrije saćastih nosača (otvori u hrptu) na vrijednost elastičnog kritičnog momenta $M_{c r}$.

Rezultati provedenih proračuna pokazuju da otvori u hrptu kod saćastih nosača imaju malen utjecaj na vrijednost elastičnog kritičnog momenta. U slučaju proračunavanih nosača, vrijednosti elastičnih kritičnih momenata dobivenih metodom konačnih elemenata za saćaste i odgovarajuće punostijene nosače, u odnosu na vrijednosti dobivene „ručnim“ proračunom prema izrazu (1), praktički su zanemarive (do max. 5\%). Može se zaključiti da se za razmatrane slučajeve elastični kritični moment može računati na isti način kao i za standardne punostijene nosače, ali uzimajući u obzir geometrijske karakteristike poprečnog presjeka kroz otvor saćastog nosača, [4], [5]. Pri tom se kod IPE ili vitkijih nosača, gdje je odnos neto i bruto geometrijskih karakteristika presjeka nešto veći, dobiju i nešto veća odstupanja, dok su ista odstupanja kod HE-A poprečnih presjeka praktično zanemariva.

\section{Literatura}

[1] CEN - European Committee for Standardization (1992): Eurocode 3 - Design of steel structures - Part 1-1: General rules and rules for buildings, ENV 1993-1-1:1992/A2:1998, Annex N

[2] CEN - European Committee for Standardization (1992): Eurocode 3 - Design of steel structures - Part 1-1: General rules and rules for buildings, ENV 1993-1-1:1992

[3] Robot Millennium v. 17.0, User's Manual, UPDATE November 2003

[4] Deljak, M. Bočno-torzijsko izvijanje čeličnih saćastih nosača / diplomski rad. Osijek: Građevinski fakultet, 2.11.2006. Voditelj: Markulak, D.

[5] Radić, I.; Markulak, D. Lateral buckling of castellated beams. // Tehnički vjesnik/Tehnical Gazette. 14, 1,2 (2007), str 25-35.

[6] Radić, I.; Markulak, D.; Varevac, D. Numerical simulation of lateral stability of castellated beams, 5th European Conference on Steel and Composite Structures - EUROSTEEL 2008, 3-5 September 2008, Graz, Austria, Proceedings, Vol. B, pp.1593-1598 